\title{
Kinetics of rabies antibodies as a strategy for canine active immunization
}

\author{
Selene Daniela Babboni ${ }^{1}$, Hení Falcão da Costa ${ }^{2}$, Luzia de Fátima Alves Martorelli ${ }^{3}$, \\ Ana Paula de Arruda Geraldes Kataoka ${ }^{3}$, Cassiano Victoria ${ }^{1}$, Carlos Roberto Padovani ${ }^{4}$ and José Rafael Modolo ${ }^{1 *}$
}

\begin{abstract}
Background: Rabies, a zoonosis found throughout the globe, is caused by a virus of the Lyssavirus genus. The disease is transmitted to humans through the inoculation of the virus present in the saliva of infected mammals. Since its prognosis is usually fatal for humans, nationwide public campaigns to vaccinate dogs and cats against rabies aim to break the epidemiological link between the virus and its reservoirs in Brazil.

Findings: During 12 months we evaluated the active immunity of dogs first vaccinated (booster shot at 30 days after first vaccination) against rabies using the Fuenzalida-Palácios modified vaccine in the urban area of Botucatu city, São Pauto state, Brazil. Of the analyzed dogs, 54.7\% maintained protective titers ( $\geq 0.5 \mathrm{IU} / \mathrm{mL}$ ) for 360 days after the first vaccination whereas $51.5 \%$ during all the study period.

Conclusions: The present results suggest a new vaccination schedule for dogs that have never been vaccinated. In addition to the first dose of vaccine, two others are recommended: the second at 30 days after the first and the third dose at 180 days after the first for the maintenance of protective titers during 12 months.
\end{abstract}

Keywords: Rabies, Dogs, Vaccination, Revaccination, Annual vaccination campaign, Fuenzalida-Palácios

\section{Findings}

Half of the world population (3.5 billion people) lives in areas where there is an increase of dogs, cats and rodents, and therefore the frequency of zoonoses transmitted by these animals is also augmented [1]. Globally, rabies provokes 40,000 to 70,000 deaths per year and approximately 15 million people receive post-exposure rabies treatment [2-4]. This means that rabies kills one person every minute worldwide [5]. Rabid dogs are responsible for $99 \%$ of these deaths and $92 \%$ of postexposure treatments [1]. In Brazil, 140 people died due to rabies between 2001 and 2010 , in $40 \%$ of these cases the disease was contracted from dogs, in $1.43 \%$ from cats, in $53.57 \%$ from bats and in $5 \%$ of the cases from other animals [6]. The protection of humans against urban rabies is achieved mainly by prophylactic measures applied to dogs and cats, which include vaccines that induce minimum antibody titers ( $\geq 0.5 \mathrm{IU} / \mathrm{L})$ [7]. In Brazil, vaccination

\footnotetext{
* Correspondence: jrmodolo@fmvz.unesp.br

'Department of Veterinary Hygiene and Public Health, School of Veterinary Medicine and Animal Husbandry, São Paulo State University (UNESP - Univ Estadual Paulista), Botucatu, São Paulo State, Brazil

Full list of author information is available at the end of the article
}

against rabies in dogs and cats is mandatory [8]. However, in mass vaccination campaigns, numerous animals do not achieve protective antibody titers after vaccinated with Fuenzalida-Palácios modified vaccine (Institute of Technology of Paraná, TECPAR ${ }^{\circ}$ ) [8-10]. The present study aimed to evaluate during 12 months the kinetics of antibodies in dogs that were first vaccinated against rabies.

The study was conducted in 2009 during the annual vaccination campaign against rabies in dogs and cats in the urban area of Botucatu ( $\left.22^{\circ} 88^{\prime} 83^{\prime} \mathrm{S}, 48^{\circ} 44^{\prime} 5^{\prime \prime} \mathrm{W}\right)$. A confidence interval of $95 \%$ and an estimation error of $10 \%$ associated with the casual participation of an animal (50\% of positive responses for participation) were considered for the determination of the sample size. In Brazil, the first vaccine shot is administered at three months of age and the booster dose should be given 30-45 days after the initial one, with subsequent annual revaccination [11].

The present study involved 576 dogs older than three months of age, which had never been vaccinated against rabies, regardless of breed, age or sex and randomly selected for blood collection. Samples were collected at five moments of the study period. The first blood sample was taken during the annual vaccination campaign against 


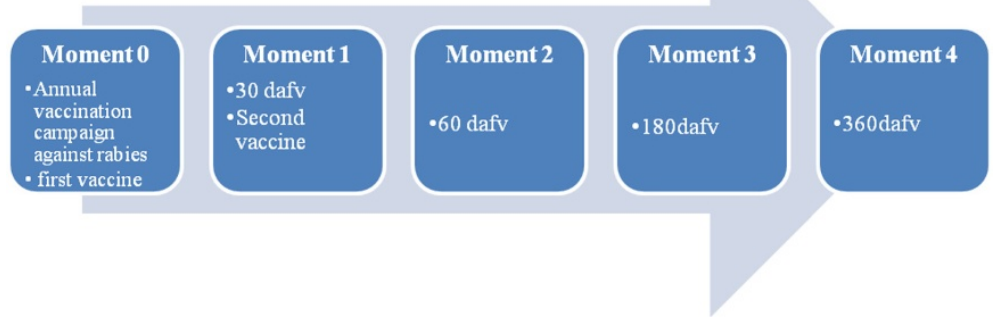

Figure 1 Experimental design of the present study.

rabies and the others on home visits, by venipuncture of the cephalic vein, saphenous or jugular (with a 3-mL syringe and $30 \times 7 \mathrm{~mm}$ needle) and placed in sterile test tubes without anticoagulant. The days of blood collection were labeled as follows: 0 (on the day of the first vaccine dose), 1 [30 days after first vaccination (dafv) and the same day as the second dose of vaccine], 2 (60 dafv), 3 (180 dafv) and 4 (360 dafv).

Thirty days after the first immunization (moment 1), dogs received the booster dose with the same type of vaccine (Figure 1). This study was characterized as longitudinal and was composed of a single experimental group, since a control group was not allowed (unvaccinated animals in a mass campaign against rabies) according to a city's law [12]. The vaccine employed in this study was from lot number $187 / 08$, each 2 -mL dose was subcutaneously injected (between scapulae), the batch was manufactured on December 16, 2008, sent to Lanagro on December 27, 2008 and released on March 6, 2008, titration (National Institutes of Health method) was $3.06 \mathrm{IU} /$ dose. Determination of serum neutralizing antibodies to rabies virus was performed at the Laboratory of Zoonoses and Vector-Borne Diseases of the Center for Zoonosis Control of São Paulo by means of the rapid fluorescent focus inhibition test (RFFIT) according to Smith et al. [13], modified by Zalan et al. [14]. A protective titer was considered when neutralizing antibodies $\geq$ $0.5 \mathrm{IU} / \mathrm{mL}$ [15]. In order to quantify the occurrence of protective titers, the frequency distribution of responses and the percentage of vaccine response among sampling periods were considered in relation to the initial moment, taking into account the loss of dogs during the study (207 died).

Of the 576 studied animals, none showed any evidence of protective antibody titers $(<0.5 \mathrm{IU} / \mathrm{mL})$ at moment 0 . One of the biggest obstacles of this research was the loss of animals, since numerous dogs run away during the study period or were killed by cars. According to reports from the owners 207 dogs (35.9\%) were lost.

Table 1 shows that $89.1 \%$ of the animals reached protective titers, indicating a growth of $12 \%$ due to the second vaccine shot. From the second moment on, the animals demonstrated a reduction in antibody titers. After $360 \mathrm{dafv}$, only $54.7 \%$ of the dogs had protective titers. The ratios between the number of protected animals and those unprotected during the study were: $8.2: 1$ at the first moment, 478:1 at the second moment, 7.7:1 at the third moment and 1.2:1 at the fourth moment (Table 1). Of the 576 dogs, 207 either died or run away. Then, of the remaining 369 animals, none was protected at the first moment, 27 (7.3\% out of 369) were protected at moments 1 and 2, 109 (29.5\%) had protective titers in the period between moments 1 and 3, 13 dogs (3.5\%) were protected only in moment $2,17(4.6 \%)$ in moments 2 and 3,12 dogs (3.3\%) had protective titers between moments 2 and 4, one dog (0.3\%) did not reach any protective level and 190 (51.5\%) animals maintained protective titers during the 360 days.

Table 1 Percentage of dogs with protective antibody titers against rabies vaccinated with Fuenzalida-Palácios modified vaccine at four different periods, 2014

\begin{tabular}{|c|c|c|c|c|c|c|c|c|}
\hline \multirow{2}{*}{ Titer } & \multicolumn{2}{|c|}{$\begin{array}{c}30 \text { dafv } \\
\text { 1st moment }\end{array}$} & \multicolumn{2}{|c|}{$\begin{array}{c}60 \text { dafv } \\
\text { 2nd moment }\end{array}$} & \multicolumn{2}{|c|}{$\begin{array}{c}180 \text { dafv } \\
\text { 3rd moment }\end{array}$} & \multicolumn{2}{|c|}{$\begin{array}{c}360 \mathrm{dafv} \\
\text { 4th moment }\end{array}$} \\
\hline & $\begin{array}{c}\text { Absolut } \\
\text { frequency }\end{array}$ & $\begin{array}{c}\text { Relative } \\
\text { frequency }(\%)\end{array}$ & $\begin{array}{c}\text { Absolut } \\
\text { frequency }\end{array}$ & $\begin{array}{c}\text { Relative } \\
\text { frequency }(\%)\end{array}$ & $\begin{array}{c}\text { Absolut } \\
\text { frequency }\end{array}$ & $\begin{array}{c}\text { Relative } \\
\text { frequency }(\%)\end{array}$ & $\begin{array}{c}\text { Absolut } \\
\text { frequency }\end{array}$ & $\begin{array}{c}\text { Relative } \\
\text { frequency (\%) }\end{array}$ \\
\hline Protected & 460 & 89.1 & 478 & 99.8 & 338 & 88.5 & 202 & 54.7 \\
\hline Not protected & 56 & 10.9 & 1 & 0.2 & 44 & 11.5 & 167 & 45.3 \\
\hline Total & 516 & 100 & 479 & 100 & 382 & 100 & 369 & 100 \\
\hline
\end{tabular}


The low concentration of antibody titers in dogs vaccinated against rabies has been previously reported [16-19]. Similarly, the immune response of dogs vaccinated only one time has already been evaluated and the results showed a rapid drop of antibody titers, which suggests that several animals are unprotected among vaccination campaigns $[10,20]$.

According to the Pasteur Institute [21], titers below $0.5 \mathrm{IU} / \mathrm{mL}$ do not protect animals against rabies. In the present study, $45.3 \%$ of the dogs that received the first dose followed by booster shot (30 dafv) did not present protective antibody concentrations after 12 months (Table 1), which is not an expected result.

The World Health Organization (WHO) recommends that $75 \%$ of the canine population of any country should be vaccinated. However, the program for rabies control of São Paulo state recommends a coverage of at least $80 \%$ $[11,22]$. In the 2009 vaccination campaign in Botucatu city, SP, the immunization coverage reached $81.36 \%$ of the animals. However, only $54.7 \%$ of the first vaccinated animals showed protective levels one year after the initial dose (Table 1).

In a study by Hirayama et al. [23] the same vaccine used in the current work was administered to animals without the booster doses. The authors found that the titers declined 120 dafv, therefore $40 \%$ of the animals did not have protective titers. In the present study, however, the drop of serum antibody titers $(<0.5 \mathrm{IU} / \mathrm{mL})$ in dogs occurred after the third time (180 dafv) (Table 1).

In Brazil, vaccination campaigns against rabies are annual and booster doses are recommended 30 to 45 days after the first shot. However, the booster dose is voluntary and the owner must take the animal to a health surveillance center to receive it [7]. In the present research, we found that after the third dose (180 dafv), $88.5 \%$ of the dogs remained protected against rabies virus (titer $\geq 0.5 \mathrm{IU} / \mathrm{mL}$ ) (Table 1 ). This value was a greater value than that found by Shimazaki et al. [24], who evaluated the immune response in unvaccinated dogs and in animals vaccinated with a single dose of Fuenzalida- Palácios modified vaccine.

Soares et al. [8] observed that 120 days after vaccination, only $58 \%$ of the studied canine population, which received the vaccine for the first time, had antibody serum titers considered protective. They also reported that 30 days after the first shot, $91.2 \%$ of the dogs had protective titers whereas Almeida et al. [9] described only $27.4 \%$. In the current study, at the fourth moment (360 dafv), $54.7 \%$ of the dogs had protective antibody titers, a higher value than that found by Soares et al. [8] who obtained $35.3 \%$ and by Almeida et al. [9] who found $18.3 \%$ in animals that did not receive the booster dose. When they discussed the determinants for the decline in antibody concentration after vaccination, it was hypothesized that the nutritional status, health status, and genetic ancestry may influence the immune response, the antibody induction and the maintenance of antibody titers in dogs [25].

\section{Conclusion}

Our present findings showed that after the first vaccination, $51.5 \%$ of the dogs had protective titers during the five study periods. After a year of this first shot, only $54.7 \%$ of the animals maintained protective antibody levels against rabies. Therefore, in order to improve protective titers against rabies for 12 months, we suggest a third dose of vaccine at 180 days after the first one.

\section{Competing interests}

The authors declare that there are no competing interests.

\section{Authors' contribution}

SDB, HFC, and JRM designed the study. SDB and HFC collected biological samples. LFAM and APAGK performed serology tests. CRP analyzed the data. SDB, HFC, CV and JRM drafted the manuscript, and all authors read and approved the final version of it.

\section{Acknowledgments}

The authors would like to thank the citizens of Botucatu city for their constant collaboration, and the team of the Laboratory of Zoonoses and Vector-Borne Diseases, Center for the Control of Zoonosis of São Paulo City, for its assistance with the serological tests.

\section{Financial support}

This work was supported by the State of São Paulo Research Foundation (FAPESP), project number 2009-09098-8.

\section{Ethics committee approval}

This study was approved by the Ethics Committee on Animal Use (CEUA) School of Veterinary Medicine and Animal Husbandry, UNESP, Botucatu, under protocol n. 64/2009. The work was carried out in accordance with the EU Directive 2010/63/EU for animal experiments http://ec.europa.eu/ environment/chemicals/lab_animals/legislation_en.htm.

\section{Author details}

${ }^{1}$ Department of Veterinary Hygiene and Public Health, School of Veterinary Medicine and Animal Husbandry, São Paulo State University (UNESP - Univ Estadual Paulista), Botucatu, São Paulo State, Brazil. ²Department of Animal Health and Production, Veterinary Medicine School, São Paulo State University (UNESP - Univ Estadual Paulista), Araçatuba, São Paulo State, Brazil. ${ }^{3}$ Laboratory of Zoonoses and Vector-Borne Diseases, Center for the Control of Zoonosis of São Paulo City, São Paulo, São Paulo state, Brazil. ${ }^{4}$ Department of Biostatistics, Botucatu Biosciences Institute, São Paulo State University (UNESP - Univ Estadual Paulista), Botucatu, São Paulo State, Brazil.

Received: 10 March 2014 Accepted: 14 July 2014

Published: 26 August 2014

\section{Reference}

1. World Health Organization: Department of Epidemic and Pandemic Alert and Response. Geneva: Swtizerland: World Health Organization: World survey of rabies No. 34 for the year 1998. Document CSR/APH/99.6; 1999.

2. Parviz S, Chotani R, MacCormick J, Fisher-Hoch S, Luby S: Rabies deaths in Pakistan: results of ineffective post-exposure treatment. Int J Infect Dis 2004, 8(6):346-352.

3. Goswani A, Plun-Favreau J, Nicoloyannis N, Sampath G, Siddiqui MN, Zinsou JA: The real cost of rabies post-exposure treatments. Vaccine 2005, 23(23):2970-2976.

4. Chulasugandha $\mathrm{P}$, Khawplod $\mathrm{P}$, Havanond $\mathrm{P}$, Wilde $\mathrm{H}$ : Cost comparison of rabies pre-exposure vaccination with post-exposure treatment in Thai children. Vaccine 2006, 24(9):1478-1482.

5. Coleman PG, Fèvre EM, Cleaveland $\mathrm{S}$ : Estimating the public health impact of rabies. Emerg Infect Dis 2004, 10(1):140-142. 
6. Secretaria de Vigilância em Saúde: Casos de raiva humana no Brasil, 1986-2010. In Brasília: Ministério da Saúde; 2010. (Accessed 07.07.2011) http://www.dive.sc.gov.br/conteudos/zoonoses/canideos_felinos/ Dados de raiva humana 1986 2010.pdf.

7. Kotait I, Carrieri ML, Takaoka NY: Raiva - aspectos gerais e clínica. In Manual Técnico do Instituto Pasteur. Número 8th edition. São Paulo: Instituto Pasteur; 2009.

8. Soares ICG, Souza MM, Lemos HN, Abreu VLV, Reis W, Campos HV, Serufo $\mathrm{JC}$, Figueiredo MJ: O cão, principal transmissor da raiva humana. Rev Bras Anal Clin 1991, 23(4):119-122.

9. Almeida MF, Aguiar EAC, Martorelli LAF, Presotto D, Brandão MM, Pereira OAC: Resposta imune humoral de cães à vacina inativa, de cérebro de camundongos lactentes, utilizada nas campanhas anti-rábicas no Brasil. Rev Saude Publ 1997, 31(5):502-507.

10. Rigo L, Honer MR: Titulação de anticorpos contra o vírus da raiva em cães, em Campo Grande, MS, na Campanha anti-rábica de 2003. Rev Soc Bras Med Trop 2006, 39(6):553-555.

11. Reichmann MLAB, Pinto HBF, Nunes VFP: Vacinação contra a raiva de cães e gatos. In Manuais Técnico do Instituto Pasteur. Volume 3rd edition. São Paulo: Instituto Pasteur; 1999.

12. Câmara Municipal de Botucatu: Lei n. 4904 de 11 de abril de 2008, No art. 78. Dispõe sobre a proteção e defesa dos animais, o controle social de sua criação, comércio, exploração e a vigilância em saúde ambiental no município de Botucatu. In Câmara Municipal de Botucatu. Botucatu: Diário Oficial.

13. Smith JS, Yager PA, Baer GM: A rapid reproducible test for determining rabies neutralizing antibody. Bull World Health Organ 1973, 48(5):535-541.

14. Zalan E, Wilson C, Pukitis D: A Microtest for the quantitation of rabies virus neutralizing antibodies. J Biol Stand 1979, 7(3):213-220.

15. World Health Organization: WHO expert commitee on rabies. Geneva: WHO; 1992. WHO Technical report series, 824

16. Kappus KD: Canine rabies in the United States, 1971-1973: study of reported cases with reference to vaccination history. Am J Epidemiol 1976, 103(2):242-249.

17. Tepsumethanon W, Polsuwan C, Lumlertdaecha B, Khawplod P, Hemachudha T, Chutivongse S, Wilde H, Chiewbamrungkiat M, Phanuphak P: Immune response to rabies vaccine in Thai dogs: a preliminary report. Vaccine 1991, 9(9):627-630

18. Sage G, Khawplod P, Wilde H, Lobaugh C, Hemachudha T, Tepsumethanon W, Lumlertdaecha B: Immune response to rabies vaccine in Alaskan dogs: failure to achieve a consistently protective antibody response. Trans $R$ Soc Trop Med Hyg 1993, 87(5):593-595.

19. Páez A, Hernández C, Escobar H, Zapata JJ, Méndez J, Rey-Benito G: Evaluación de la seroconversión como respuesta a la vacunación antirrábica en perros en el departamento del Valle del Cauca, Colombia, 2009. Biomédica (Bogotá) 2011, 31(4):474-484.

20. Da Silva GC P: Soroprevalência de aglutininas anti-Leptospira e reação anti-Brucella em cães no município de Cuiabá, Mato Grosso, Brasil. In Masters dissertation; 2010. Universidade Federal de Mato Grosso, Faculdade de Agronomia e Medicina Veterinária; 2010 [http://www.livrosgratis.com.br/ arquivos_livros/cp147078.pdf]

21. Costa WA, DeÁvila CA, Valentine EJG, Reichmann MLAB, Panachão MRI, Cunha RS, Guidolin R, Omoto TM, Bolzan VL: Profilaxia da raiva humana. In Manual Técnico do Instituto Pasteur, Volume 4. 2nd edition. São Paulo: 2000.

22. Consales CA, Bolzan VL: Rabies review: immunopathology, clinical aspects and treatment. J Venom Anim Toxins ind Trop Dis 2007, 13(1):5-38. http:// www.scielo.br/scielo.php?script=sci_arttext\&pid=S1678-91992007000100002.

23. Hirayama N, Raharjo Jusa E, Aeny Rochman Noor M, Sakaki K, Ogata M: Immune state of dogs injected with rabies vaccines in the west Java, Indonesia. Nihon Juigaku Zasshi 1990, 52(5):1099-1101.

24. Shimazaki Y, Inoue S, Takahashi C, Gamoh K, Etoh M, Kamiyama T, Makie H: Immune response to Japanese rabies vaccine in domestic dogs. J Vet Med B Infect Dis Vet Public Health 2003, 50(2):95-98.

25. Blancou J: Las vacunas y la vacunación antirrabica de los animales domésticos y salvajes en Europa. Rev Sci Tech Offint Epiz 1995, 4(2):261-272.

doi:10.1186/1678-9199-20-37

Cite this article as: Babboni et al:: Kinetics of rabies antibodies as a strategy for canine active immunization. Journal of Venomous Animals and Toxins including Tropical Diseases 2014 20:37.

\section{Submit your next manuscript to BioMed Central and take full advantage of:}

- Convenient online submission

- Thorough peer review

- No space constraints or color figure charges

- Immediate publication on acceptance

- Inclusion in PubMed, CAS, Scopus and Google Scholar

- Research which is freely available for redistribution 